\title{
Open, interdisciplinary and collaborative educational innovation to train in energy sustainability through MOOC: perception of competency development
}

\author{
Luis Cachay-Huamán ${ }^{1}$. Darinka Ramírez-Hernández²
}

Received: 22 January 2019 / Accepted: 3 May 2019 / Published online: 22 May 2019

(c) The Author(s) 2019

\begin{abstract}
This research on open, interdisciplinary and collaborative innovations called, "MOOC (Massive Open Online Courses)," analyzes the responses of 2799 participants about their perceptions of achieving their professional development goals and the competencies they sought to have acquired by the end of the course compared to their expectations at the time of course registration. The first four MOOCs analyzed covered topics in Energy Sustainability and were offered in 2017-2018 with a total of 17,210 participants. This research used a mixed methodology to analyze the responses of the participants of these online courses on energy sustainability (offered by the Binational Energy Laboratory Project: https://energialab.tec.mx/). The results show that the participants of the MOOC do perceive that they have developed professionally in training on energy issues and that they now have open to them new business opportunities and new professional relationships. In addition, through successful completion of the MOOC, they have strengthened their perseverance and self-study skills as well as the use of information and communication technologies. The students' time management is perceived as one of the principle challenges in the learning processes of MOOCs.
\end{abstract}

Keywords Competencies $\cdot$ Educational innovation $\cdot$ Energy sustainability $\cdot$ MOOC $\cdot$ Open educational innovation . Perception

\section{Introduction}

The collaboration among expert educators, trained in a variety of disciplines, working together on open access projects may help create new possibilities for people to have formative opportunities throughout their lives. This linkage of perspectives provides opportunities to develop knowledge through shared projects in the open innovation field [1, 2], given its free access and the interdisciplinary, diverse and collaborative community contributions [3]. Massive Open

Luis Cachay-Huamán

cachay_1@up.edu.pe; luiscachay@gmail.com

Darinka Ramírez-Hernández

darinka@tec.mx

1 Centro de Educación Ejecutiva, Universidad del Pacífico, Jr. Sánchez Cerro 2141, Jesús María, Lima, Peru

2 Escuela de Humanidades y Educación, Tecnologico de Monterrey, Av. Eugenio Garza Sada 2501 Sur 64849, Monterrey, Nuevo Leon, Mexico
Online Courses (MOOC) are found among the innovative projects that can offer these formative experiences throughout life. Thus, the main objective of the present investigation is to determine that, if by completion of the Massive Open Online Courses (MOOC) that were developed by the binational laboratory (https://energialab.tec.mx/), the participants in these courses perceived that their expectations were met and that the commitment that inspired them to sign up led to accomplishment. Also, it was important to know if they felt that the MOOC allowed them to apply, develop and improve cognitive and collaborative skills related to areas of specialized knowledge and the management of information technologies for learning (ICT).

To develop this study, educators from a Mexican institution worked with two research groups during the design of the MOOCs for training in energy sustainability. This collaboration between groups representing Energy and Climate Change from the School of Engineering and Research and Innovation in Education from the Humanities and Education School brought an innovative synergism to the production of the MOOCs. Emerging 
from a joint project called, "The Binational Laboratory," from Mexico and the United States, this collaboration among multidisciplinary educators was supported by the National Science, Technology and Research Institution from Mexico (CONACYT), the Energy Department from the government (SENER) and the Tecnologico de Monterrey (TEC). The "Binational Laboratory for the intelligent management of Energy Sustainability and Technological Training" project is comprised of four elements to be developed: infrastructure; specialized human resources; research capabilities; and interdisciplinary- interinstitutional-binational projects (Fig. 1).

The binational laboratory aims to offer high-impact solutions to sustainability challenges faced by the Mexican energy sector to do the following: (a) increase specialized human resources; (b) solve specific demands for technological research; (c) develop smart technologies for the energy-value chain (electricity); and (d) make available nationwide a curriculum based on MOOC technology to overcome training shortages. Its ambitious goals are reflected in the number of professionals decided as a target $(15,000)$ to receive certification. This number would cover part of the demand for professionals generated by the energy reform in Mexico.

The relevance of this research lies mainly in that the collected research data and conclusions obtained will serve entities in all fields of education to improve the design and implementation of MOOCs. Likewise, the research will provide statistically significant support to underpin the learning methodologies, activities and techniques that need to be promoted and incorporated in the design and implementation of the MOOCs.

\section{Theoretical frameworks}

Energy sustainability is currently considered one of the most important and urgent topics in recent history. Because of environmental conditions, shortage of non-renewable resources and even the economic crisis, it has become necessary to look for new, less-polluting energy sources, which can also be made easily available to the population in general. Jiménez Herrero [4] states that energy sustainability is considered a new ethical approach that negotiates between society and the environment with a focus on long-term permanence and is the responsibility of the current generation to itself and future generations.

The World Commission on Environment and Development (WCED), established by the United Nations (UN) on 19 December 1983, defines sustainability as a way of life that extends from an individual necessity to a sustainable development in a general sense. It can also be defined usefully as, "development that satisfies the necessities of the present time without compromising the capability of the future generations to satisfy their own needs" [5] (p. 4). According to Willrich [6], it is important to note that the benefits of energy sustainability reach beyond environmental effects, because it is also highly important for the development of nations and is directly related to economic factors that constitute stability and social improvement, since energy sustainability is the result of direct interactions among countries. Furthermore, he notes that energy sustainability must be assumed from an interdisciplinary perspective and as a critique towards non-sustainable attitudes that are held in society in order to generate discussion and conscious action capable of guiding us towards development [7-10].

In addition to the important role of training professionals in Energy Sustainability, MOOCs incorporate attributes
Fig. 1 The Binational Laboratory for the intelligent management of Energy Sustainability and Technological Training. Webpage: https://energialab .tec.mx/

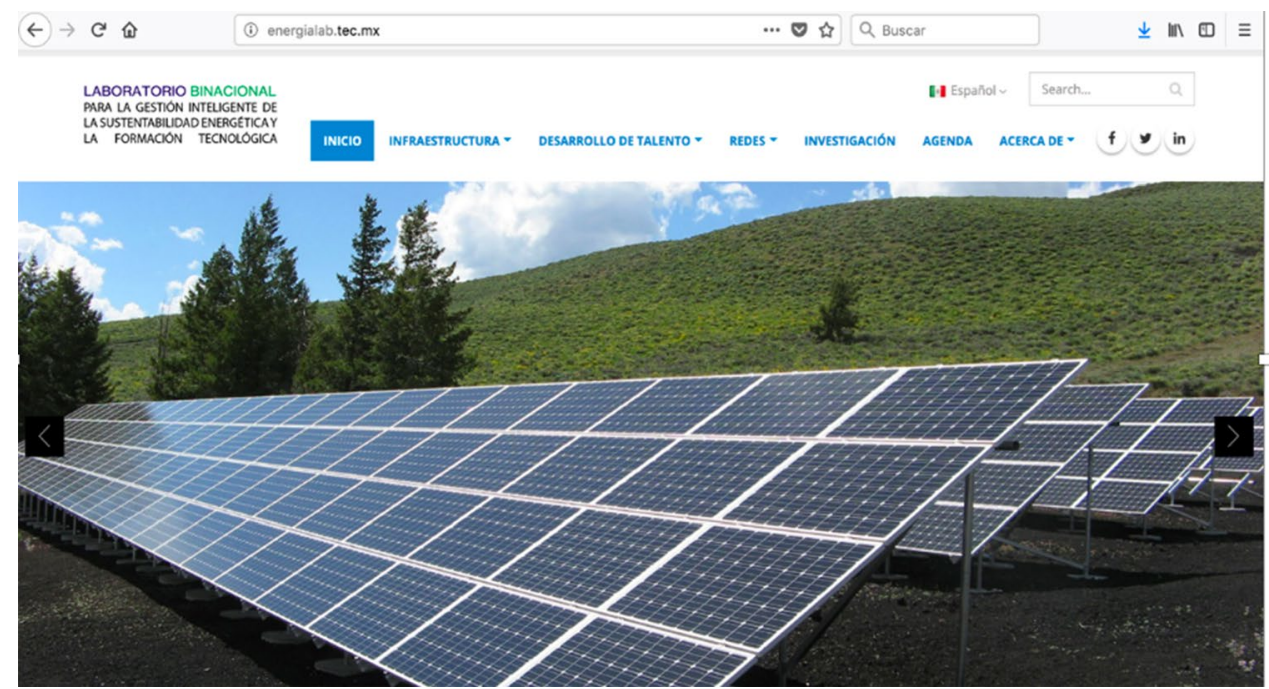


of the Open Educational Movement, such as gratuity and accessibility [11], and they are characterized by being open, participatory and distributed [12-14]. On the other hand, the sustainable development of a country depends on how reliable and stable the supply of energy is and whether it is reasonable in cost and in harmony with its environmental and social requirements [15]. This could have a positive correlation with the level of prosperity of its citizens [16]. Given the above, it is relevant to investigate the competencies that are developed in these MOOCs.

We live in a changing world, which demands increased innovation by educational institutions to deliver sufficient and timely training to professionals. These changes derive from the ways in which information and communication technologies (ICTs) have impacted our society in the last three decades. MOOCs emerge as one alternative response to the need for knowledge and training in a modality very adapted to the current rhythms of life.

Massive Open Online Courses (MOOCs) are classes taught via technology platforms that extend the teaching-learning process to thousands of students at one time. They have emerged as a response to the challenges faced by educational institutions and organizations in critical times of information need, because they can deliver demanded training to a large population that seeks quality education at low cost [17].

MOOCs have also had to respond to the needs of the socalled current generation of digital natives who rely on ICT to perform and simplify tasks, whether for work or school, thereby making greater the challenges to which these types of tools must respond. Having said that, ICTs have made progress and have improved an increasing number of fields of knowledge to the degree that, today, we are dependent upon these technologies to perform almost any activity, no matter how simple it may be. The technologies arise as a response to the needs of the user community itself, which demands a great diversity of tutorials, guides or complete courses in areas of technology, economics and other topics of interest. Therefore, the developers of MOOCs have the challenge of understanding and satisfying the need for ever-increasing consumption by consumers of reliable information.

Perhaps the greatest challenge for the MOOCs is to improve the completion rate of the people who enroll in these courses for learning, because, although there is a high rate of enrollment, it is also true that more than $60 \%$ do not finish, according to the data from the SCOPE report (2013) [18]. In addition to this, the form of evaluation in MOOCs has been much criticized for its rigid modality and, to a certain extent, the behavioral reliance mainly on the use of memory for the learning processes. The students of a MOOC want the teacher himself to provide feedback in their learning process. The massive number of teaching-learning processes has forced universities and educational institutions that teach through these types of courses to reduce them into modules in order to minimize costs. It also requires that the students be autonomous and self-regulate their own learning.

Competencies are a set of knowledge, skills and abilities, which, in combination with certain attitudes and values, empower a person to face the various situations that arise throughout their existence [19]. In this sense, these authors add that effective performance in the labor field depends on a set of variables. Although there is a consensus that generic competencies constitute the substratum on which the impulse to learn is sustained, long-term learning and the ability to adapt and/or consolidate specific competencies depends on contexts. These authors emphasize that the lines of research on learning and competency assessment focus on student-centered processes dependent on the use of virtual and collaborative tools and the training of teachers to have the capacity to apply these tools.

On the other hand, professional development is a variable that depends on the motivation and decision of each individual. In addition, the generalization of the use of digital tools demands new skills of communication and collaboration in order to facilitate the management of relationships in the virtual field. It requires skills that allow critical perception of the progress of self-learning and its effective application [20]. Similarly, with respect to the open educational movement, pending challenges to tackle are the development of didactic digital competencies simultaneously with the design of more advanced models of distance learning [21, 22]. This present investigation is related to these concepts.

The definition of professional development involves activities aimed at improving the practices of a professional in the areas in which he works through life-long learning [23]. Usually, the definition is restricted to the period after graduation and can be found in the bibliography and equivalent terms that describe professional development, education or continuing education [24]. On the other hand, with the purpose of analyzing how professional development can change in social and labor contexts, some authors allude to the current debate about whether this educational space is designed and built by educational or productive entities as a response to supply or demand, figuratively [25]. A set of criteria that has been identified to examine a training system from the economic and strategic point of view includes relevance, coherence, compliance, efficiency, timeliness and adherence [26]. This highlights the importance of developing adequate skills to face increasing uncertainty in the workplace. The training systems and criteria distinguish the resources to act with competence, the professional activities that are developed with competence and the real actions of the workers.

If professional development is relevant, and currently there are the necessary technological tools available to everyone, such as MOOCs, why not use them for the 
professional development of the community in general? In a study on the quality of MOOCs, the terminal efficiency of the MOOC offered in the platform, "MexicoX," (the number one platform of digital learning in Mexico) during the year 2016 was calculated to be $19.4 \%$ [27]. The authors also point out that, in this way, their vision of "positioning quality educational offering at an international level" has been successfully built through open, free and online courses of national and international educational institutions" [27] (p. 6). Through the MexicoX platform, twelve MOOCs have been developed for the 2016-2019 period, and it is noted that the terminal efficiency has been $16 \%$, significantly higher than the global average of 5\%.

\section{Methodology}

For this research, the mixed method of investigation has been applied, starting from the research-design process and going through the data collection and analysis. A triangulation design approach was deployed using a convergent model with three stages: quantitative, qualitative and convergent (Fig. 2). The data collection and the obtaining of results of the qualitative and quantitative analysis procedures were developed in a parallel way. Finally, they were compared and contrasted in a convergent stage in which the results were interpreted to reach conclusions based on both [28].

The advantages of the triangulation approach are that it provides greater confidence and validity to the results, more creativity in the development of the study and flexibility to interpret the results. However, when applying it, some pieces of data might be set aside without exhaustive examination, or biases may arise from various sources [29].

Being part of the Energialab project makes this investigation experience unique, with no similar previous references which could be approached as a single case with mixed methods of research. Thus, the research question of this study is answered, and the objectives of this study are achieved through the use of a combination of quantitative and qualitative analysis tools applied to a set of data that was empirically obtained through questionnaires that allow the identification of the MOOC participants' perceptions. This framework permits exploring a phenomenon that is barely known or described in detail [30]. Additionally, among the five types of cases (critical, unusual, common, revelatory or longitudinal) cited by Yin $(2009,2014)$, the rationale to label this as a single case fits the revelatory type, because it has not been studied previously [30,31].

In order to achieve quantitative objectives, two hypotheses were proposed:

Null hypothesis Upon completion of the MOOC and with respect to the expectations that led them to enroll, students value equally the results obtained in the aspects of professional development compared to the specific competencies acquired (Fig. 3).

Alternative hypothesis When completing the MOOC and regarding the expectations that led them to enroll, students' value differently the results obtained in the aspects of professional development compared to the specific competencies acquired.

\section{DESCRIPTION OF THE METHOD}

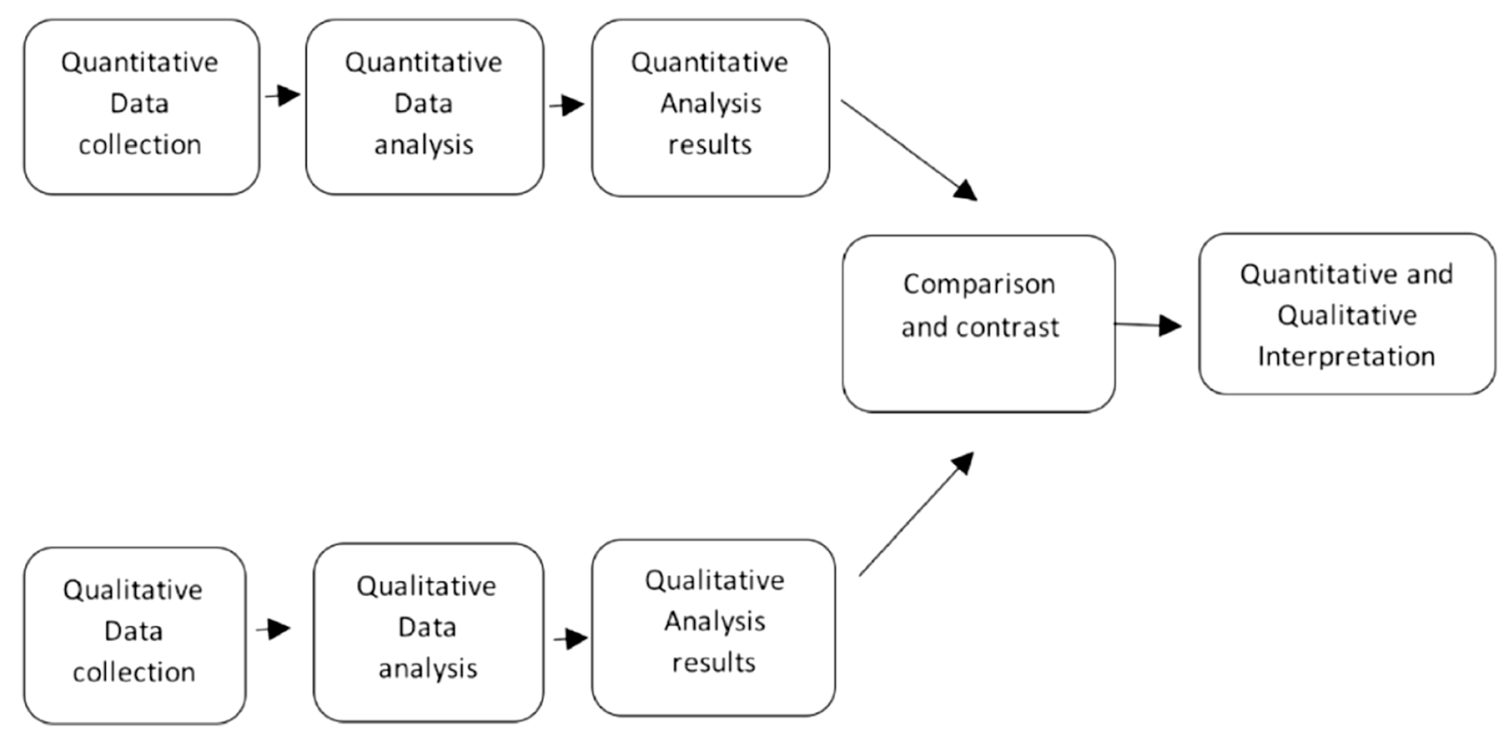

Fig. 2 Mixed research method with a convergent triangulation design approach (Source: adapted and translated by Cresswell and Clark [28, page $63, \mathrm{~b}])$ 
Fig. 3 Simplified scheme of the research quantitative framework

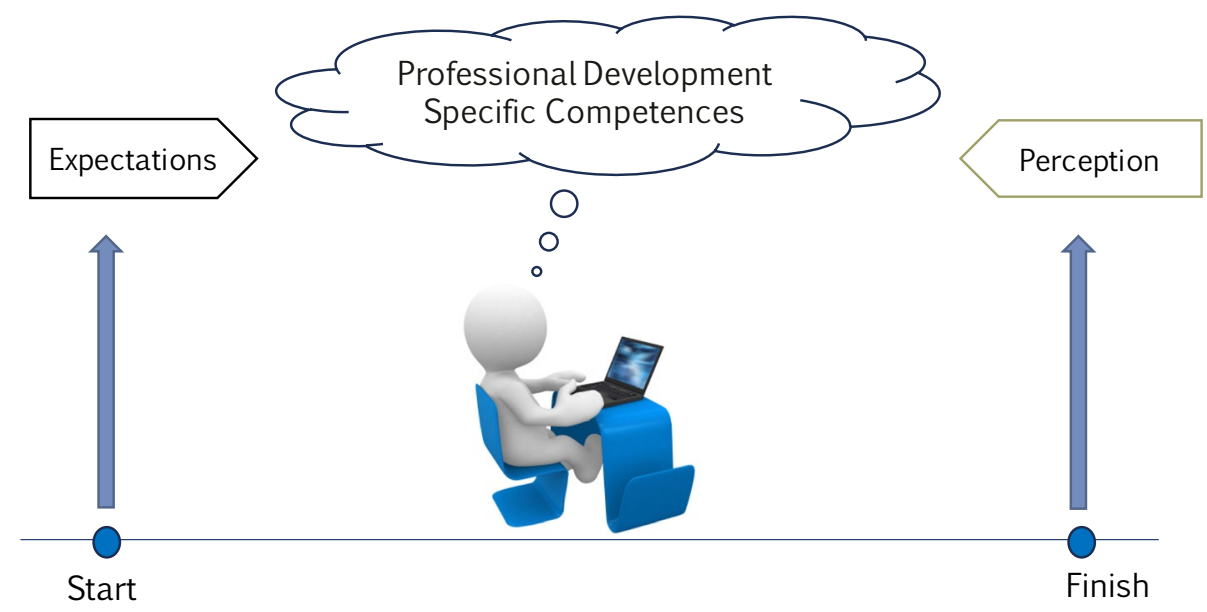

The qualitative objectives of this research aimed to reveal what is the students' level of commitment to the course and what are the factors that affect it.

As is prescribed in a mixed method research, information was collected for both the quantitative and qualitative stages. Web-based, systematic-and-structured-data-collection procedures aimed to obtain direct information from students their perceptions about their learning motivation and experience at the beginning and at the end of the MOOC, respectively [32]. This ensured a robust capture of responses and, at the same time, a cost-efficient way to obtain a large amount of information.

The courses are delivered in an open-fashion mode using the MexicoX platform. This study involves the first four massive courses of the project (https://energialab.tec.mx/):

- Energy: past, present and future.

- Energy reform in Mexico and its opportunities.

- The new electrical industry in Mexico.

- Conventional energies, clean energy and its technology.

Participants in the quantitative section consisted of a finite convenience sample that corresponds to the total number of participants of the four MOOCs mentioned above, who not only took the MOOCs, but also passed them. Out of 17,210 participants in the MOOCs, 2799 passed, of which 1996 answered the Likert scale questionnaire. The latter are the units of analysis for this study. It was important to analyze what the students thought about the MOOCs, as they provided this study with information regarding the product; that is, the MOOCs designed in collaboration by engineers and education experts. The demographic data of the sample studied is the following: $38.6 \%$ women and $61.4 \%$ men; $26.6 \%$ of the participants had a high school education, 9.2\% had a technical degree, $47.3 \%$ had a bachelor's degree, $11.7 \%$ had a master's degree, $1.2 \%$ had PhDs and $4.1 \%$ had other educational backgrounds. Participants mostly belonged to 20 different countries in Latin America, while some participants were from Canada and Spain.

The sample for the quantitative section was obtained from the answers to the final questionnaire of 2799 MOOC participants who finished each of the courses on the MexicoX platform [33] and received certificates in April 2017. This instrument had 17 questions on the Likert scale with four closed answers: strongly agree, agree, disagree and strongly disagree. The survey consisted of three sections; namely, identification data, interests for professional development and competencies acquired with the MOOC [34].

In the second section, there are seven questions about the interests and motivations for professional development that led the student to enroll in the MOOC [35]. It combines multiple choice and Likert-type items used to obtain information about the degree of satisfaction of the students regarding the contribution of the course to improve their professional development, considering the following aspects: training needs, professional development and business opportunities, professional relationship with people with similar interests, academic training, perseverance and learning skills and use of information and communication technologies (ICT) to complete the course successfully.

In the last section, there are six questions with Likert scale multiple choice answers about whether the course allowed the student to acquire or improve in the following specific competencies: digital competencies related to internet and office automation, use of the technological platform, obtention of relevant information, use of social networks for academic purposes, basic knowledge of the topics of the course and development of practical experience in the area of energy.

For the qualitative section, the chosen discretionary sample was obtained from 83 participants (out of the 1996) who, in addition to the closed Likert-type items, answered an open question about their level of commitment to the course, which was part of the initial questionnaire. This is 
comprised of 28 items grouped in three sections: identification, interests and motivation, and prior knowledge. The second section includes a question that inquires about the commitment of the student to complete the course.

The closed-answer alternatives refer to (i) their interest in obtaining the certificate; (ii) whether they will perform activities and exams independently of the certificate; (iii) their interest in finishing the course; (iv) their willingness to consult the material or (v) their becoming aware of the content without completing the full course. It also includes option (vi), other, which allows an open response and has been used additionally as a source of data for qualitative analysis.

The elaboration, triangulation and piloting of the qualitative and quantitative instruments were developed in a previous phase by the Research Group of Innovation and Education of the Tecnologico de Monterrey and by researchers of the Openergy network of the project [34] for the purpose of obtaining validity of content and structure for the instruments used. Likewise, a series of consultations was carried out with education experts regarding the relevant constructs for building the surveys [35]. Likewise, its structure was validated with a reliability analysis based on the Cronbach's alpha coefficient, after having analyzed its structure using the Exploratory Factor Analysis strategy and the factorial solution method of the main-axis-with-oblique-rotation strategy [34].

Data collected through the quantitative stage was processed with a descriptive statistical analysis, and a $\mathrm{Z}$ test was applied in order to confirm the research hypothesis. Simultaneously, a qualitative analysis was performed from the open answers of the students to the commitment level question. Finally, the results of both stages were compared, contrasted and interpreted jointly.

The quantitative analysis used the answers' data to identify whether, at the end of their courses, the students perceived that the expectations that led them to enroll were fulfilled and, furthermore, that the MOOCs allowed them to apply, develop or improve cognitive and collaborative competencies in the areas of specialized knowledge and in using ICT for learning purposes.

The reliability analysis required splitting items into two groups; namely, one for the professional development factors and the other for the acquired competencies. The responses were rated from 1 to 4 with 1 for Strongly Disagree, 2 for Disagree, 3 for Agree, and 4 for Strongly Agree. This transformed the ordinal variables to metric variables.

The Cronbach's alpha coefficient was calculated for each group and for the total responses of the final survey. The results confirmed its reliability, which is defined as the degree to which a multi-item instrument consistently measures a sample of the population so that, when the Cronbach's alpha coefficient is between 0.70 and 0.90 , it is a sign of a good internal consistency of the answers [36]. Table 1 shows the reliability results of the students' answers to the final survey, where in each case, $\alpha>0.70$.

\section{Results analysis}

The data analysis strategy is different for each stage of the investigation. A general characteristic of the mixed method of research is the methodological eclecticism, which leads the researcher to select the best available techniques to solve the research questions [37]. The quantitative stage takes the data collection and applies statistical procedures to describe the central tendencies of the responses and their dispersion. In the qualitative stage, the data taken from the answers of the participants are interpreted from previous assumptions, seeking to identify the elements of the student's commitment and the challenges that he perceives in the MOOC development process.

The quantitative analysis of this research is based on the positivist paradigm, which is based on an objective, rigorous and reliable measurement [38] of the variables that support the hypotheses and help answer the research question. In addition, some elements of the qualitative approach have been incorporated to enrich this research with mixed methods [39].

The student population had $41 \%$ graduate level and 33\% bachelors, $62 \%$ men, $68 \%$ teaching-related professionals and $62 \%$ students under 30 years old [40]. Out of the total number of students who received participation certificates, 1294 answered all the questions in the survey, and the statistical analysis was carried out on this information (see Table 2), that corresponded mainly to the first four MOOCs.

Three groups of variables were defined in order to carry out the quantitative analysis: PROSDPR for the values of the answers on aspects of professional development; PROSCOM for the values of the answers on acquired competencies and, finally PROSTOT for the total evaluation of the MOOC. Then, a descriptive analysis was carried out to estimate the average and the dispersion of these variables [31].

To accomplish the purpose of the research and in order to verify the quantitative hypotheses, the following steps were followed:

1. Identification of the type of test to be performed.

Table 1 Results of the reliability test

\begin{tabular}{llll}
\hline & $\begin{array}{l}\text { Professional devel- } \\
\text { opment answers }\end{array}$ & $\begin{array}{l}\text { Acquired compe- } \\
\text { tencies answers }\end{array}$ & Total \\
\hline $\begin{array}{l}\text { Cronbach's alpha } \\
(\alpha)\end{array}$ & 0.839 & 0.867 & 0.915 \\
\hline
\end{tabular}


Table 2 Distribution of students who answered final survey, by MOOC

\begin{tabular}{lcc}
\hline MOOC Name & $\begin{array}{l}\text { Percentage of complete } \\
\text { answers (\%) }\end{array}$ & $\begin{array}{l}\text { Number of } \\
\text { complete } \\
\text { answers }\end{array}$ \\
\hline Energy: past, present and future & 40.3 & 521 \\
The Mexican energy reform and its opportunities & 31.1 & 402 \\
The new electric industry in Mexico & 18.6 & 241 \\
Conventional, clean energy and its technology & 9.3 & 120 \\
Energy saving & 0.5 & 6 \\
Energy markets: business opportunities & 0.2 & 2 \\
Transmission & 0.1 & 1 \\
Distribution & 0.1 & 1 \\
& 100.0 & 1294 \\
\hline
\end{tabular}

\begin{tabular}{llllllllll}
\hline Variable & Avg & SE & StdDev & Var & VC & Median & Mode & Assim & Kurtosis \\
\hline PROSTOT & 3.4986 & 0.0116 & 0.4171 & 0.1740 & 11.92 & 3.5385 & 219 & -0.80 & 1.26 \\
PROSDPR & 3.4938 & 0.0117 & 0.4205 & 0.1769 & 12.04 & 3.5714 & 265 & -0.73 & 0.84 \\
PROSCOM & 3.5041 & 0.0129 & 0.4626 & 0.2140 & 13.20 & 3.5 & 372 & -0.83 & 1.19 \\
\hline
\end{tabular}

2. Choice of level of significance.

3. Determination of the zone of acceptance or rejection of the Null Hypothesis.

4. Determination of the statistical calculation function.

5. Conclusion of the test in acceptance or rejection of the Null Hypothesis.

Data was arranged so that the answers represented variables related to the competencies under analysis. The groups of variables used for the descriptive statistical analysis is shown in Table 3.

The results of the answers for each group of PROSDPR and PROSCOM questions referred, respectively, to the average of the questions on professional development and the deployment of learning and technology management competencies, and the total variable (PROSTOT) had an average close to 3.5 within the Likert rating scale, which is considered a high valuation, because it lies between the favorable (agree) and very favorable perception (strongly agree). Likewise, the medians of the three variables are very close to each other. This fact reflects that the responses on the evaluations of the students' perception of the aspects of professional development and of the acquired competencies are similar.

The variance of the PROSCOM variable is different from the variances of the other two variables (PROSTOT and PROSDPR), which would lead us to conclude that, in the former, the perceptions of the students are more dispersed, despite being equally high on average. The same can be concluded from the greater coefficient of variability of the variable PROSCOM in relation to the other two.

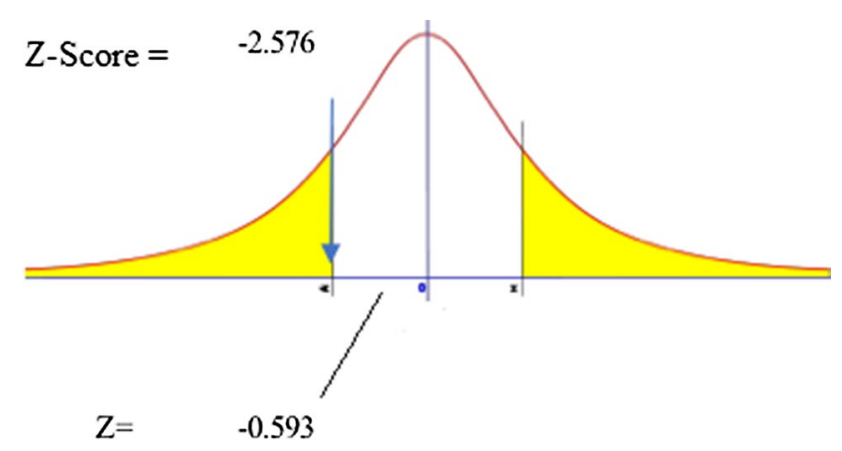

Fig. 4 Acceptance graph of the null hypothesis

The $\mathrm{Z}$ estimator is used because it corresponds to a sample of large size, greater than 30 data [41]. Subsequently, the Minitab V.11.0 application was used to perform a $\mathrm{Z}$ test for means of two samples. Since the calculated statistic -0.593 is smaller than the $\mathrm{Z}-2.576$ statistic, then the Null Hypothesis is accepted (Fig. 4).

The conclusion of the analysis is that there are no significant data that lead to reject the Null Hypothesis. So, it is accepted that the means of both groups of variables are equal. With this, it is accepted that students value equally the results obtained at the end of the MOOC with respect to their initial expectations of professional development that led them to enroll and their assessment of the skills obtained.

The qualitative analysis seeks to understand the perception of the participants in relation to their commitment to the course at the time of registration in order to assess what are the elements and the relevant challenges they perceive 
will be faced during the MOOC. A mixed instrument was applied, which combined closed questions with options proposed by the researcher and also an open option, which allowed the student to broaden his opinion regarding the commitment.

The analysis of the qualitative data was not standard and began with the detailed review of the open responses of the participants. It was constructed as it was fed from the successive findings, thereby giving a structure to the unstructured data [29]. In this stage, the closed answers showed that 81 percent of the students planned to carry out the course activities in order to obtain a certificate; $15 \%$ planned to finish the course, even if they did not receive a certificate; and $2 \%$ only wanted to partially complete the course or consult its material in order to have a general idea of the content. According to the literature review, most of the MOOCs are free [42], and this allows people to get a certified education, especially, people who previously have not been able to continue a traditional type education for economic reasons [43]. The main reason for this is that most MOOCs deliver the certifications free for those who take the courses.

After this finding, the analysis began of the 83 responses given to the open part of the question that reveals the level of commitment by the students to the courses. In the successive-analysis steps, the elements present in the commitment statement were identified, and their influence on it was assessed as well as the factors that were considered objections or limitations to completing the MOOC.

In this stage, the research process works with the words and phrases literally declared by the students and builds, from successive inductive iterations, a model of components that define the level of commitment of the students to the course. After preparing and filtering the data, the following steps were developed following the intuitive guidelines for the data analysis, proposed by Monje-Alvarez (2011) [44]:

1. Recognition of the patterns with which the data appear.

2. Coding or grouping of the data according to similarity criteria.
3. Categorization or segmentation into singular elements that are relevant from the point of view of our research.

4. Classification, synthetization and comparison, which lead to show conclusions for the group of interviewees in relation to the research question.

According to this author, "in the discovery phase, the researcher must recognize the patterns with which their data emerge, examining them in all possible ways" [44]. Thus, the first exercise of our qualitative analysis consisted in the identification of the recurrent words in the narrative of the answers of the respondents and quantifying their frequency of appearance.

The identified words were given a contextual meaning associated with the question about the commitment to the course and grouped together with words of similar meaning. Then, with these words were associated phrases that had connection with these groups of meanings. Finally, the words and phrases were coded and sub-coded in relation to the commitment statements and the elements that composed them. The subsequent analysis of these codes, whose meaning arose directly from the students' statements, allowed the construction of categories, which grouped the previous levels. On a recurring basis, the statements were reviewed, identifying in them the elements of the student's commitment, both positive and negative, favorable and unfavorable.

Finally, the identified categories were related to the objective of this investigation, reflected through the research question, which inquired about the perception of achievement of specific, professional competencies developed through MOOCs.

For the data array and its tabulation, the Microsoft Excel spreadsheet and the Atlas TI 8.0 application were used for the analysis of survey responses, word counting, word-cloud construction and identification of the words and phrases most relevant to the opinion on the level of commitment to the courses.

The results of the qualitative analysis (Table 4) showed that the components of the student's commitment were

Table 4 Analysis of the components of the students' answers regarding their commitment

\begin{tabular}{|c|c|c|c|c|c|c|}
\hline Manifest will & Propose action & Identify instrument & Express motivation & $\begin{array}{l}\text { Identify object that } \\
\text { interests you }\end{array}$ & $\begin{array}{l}\text { Declare ulterior } \\
\text { purpose }\end{array}$ & Express limitation \\
\hline Plan & Develop & All the course & To give the best & Knowledge & Application & Time \\
\hline I will do my best & Finish & The course & I an really interested & $\begin{array}{l}\text { To learn about } \\
\text { energy }\end{array}$ & Personal investment & Schedule \\
\hline I want & Do & Assessment & I am interested & More knowledge & Work & But \\
\hline I will try & Learn & Activities & & Certificate & Development & Costs \\
\hline Maybe & Acquire & Lectures & & Subject & Create a plan & Other MOOCs \\
\hline I think & Review & Contenido & & Diploma & Take advantage of & I do not know \\
\hline I do not have a will & Read & Videos & Not interested & & To open doors & \\
\hline
\end{tabular}


stated through words and phrases whose values affected their performance positively (upper) or negatively (lower). Among them, it was found that the students' time management was one of the main challenges in the learning processes of MOOCs. On the other hand, the declaration of an ulterior purpose always reflects a potential favorable impact on the commitment to the course.

In opposition, students' opinions also slipped objections or limitations perceived by them at the beginning of the course; namely, time, schedule, study load, costs and other economic aspects.

Among some of the limitations in the literature review about MOOCs, we found the following:

That access can only be obtained by people who have connection to the internet and a computer [45].

The student should have basic knowledge in the use and handling of the ICT [46].

Some MOOCs have a cost and a registration limit [47, 48].

There is a significant dropout rate in these courses [47, 48].

The duration could depend on the user in the case of the free access and no-cost courses [48].

Some MOOCs charge for the expedition of the certificate once the course is concluded because of the prestige of the institution that offers such a course [48].

The maintenance of the MOOCs is expensive for the organization that offers them [42].

Through a process that uses inductive logic, students' responses were reviewed, and their meanings were linked to the following aspects that constituted the axes of their commitment and that were manifested in words or phrases that have a contextual meaning that affirms or weakens the value of the declared commitment. The simplified model that results from the synthesis of coding and interpreting the contextual meaning of words and phrases (Fig. 5) shows the main components of the student's commitment.
To illustrate the inductive process, consider, as an example, the words certificate, proof and diploma: These are associated with the object of interest of the student, which is to study the course in order to obtain a certificate. There are also words such as take, project and investment, whose contextual meaning is associated with the purpose of generating value for their careers afterwards and is based upon the knowledge acquired in the course.

The strength of having the results of this part of the research are visible when an instructional designer is capable of building a learning process by going through the various components and identifying specific methods, tools and resources that make an optimum combination that will improve the learning process.

For example, focusing on the willingness to study, the designer can propose preliminary forums or advice sessions to assess the starting situations of the students. In addition, the advisors may deliver introductory information that aims to focus the response of the students on topics that will help them to use the platforms or resources. Going forward, periodical surveys may be launched to identify bias or gaps in the process and activate a set of coaching sessions. Finally, the instructional sessions can be split into modules of gradually rising complexity so that the certificate, which is the thing important to the student, can be earned.

This approach to understanding the commitment of a student is key in assessing the potential success of a MOOC, given that the nature of these resources rely on the learning skills of the students. Notwithstanding, many of the positive results of MOOCs have their origin in the use of innovative tools that take advantage of ICT by promoting frequent contact through social networks and the mobile learning protocols.

It is not a surprise that these results are partially aligned with those statements that emphasize that the MOOC quality indicators increase with a distance education strategy that includes attractive technological resources as well as permanent communication that promotes interaction and student response [49, 50]. With these elements present in the MOOC design, the engagement of the student is strengthened.

Category Analysis

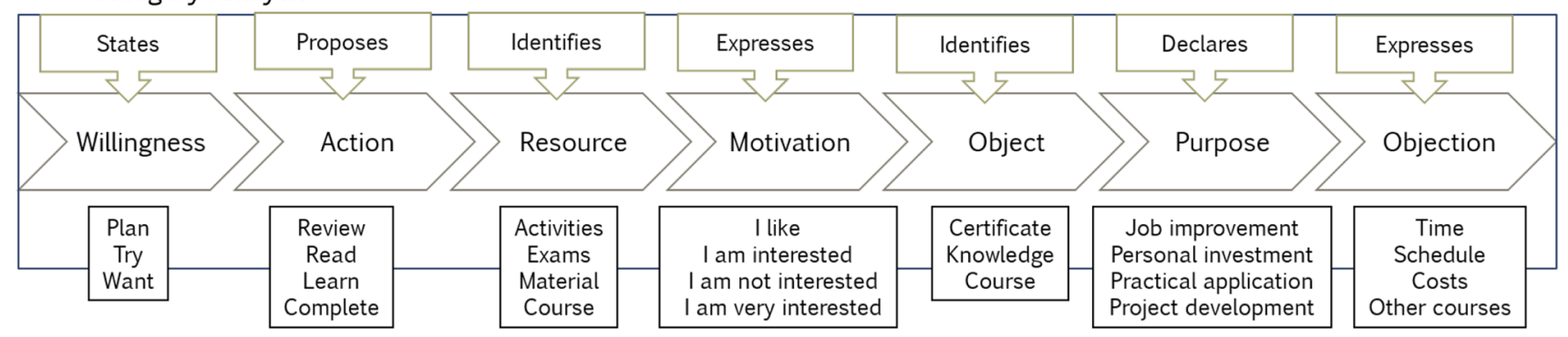

Fig. 5 Category model of the components of the student's commitment 
However, there is still room to focus on the long-term purposes of the learning process and on the objections that arise mainly due to scarce financial resources or tight schedules of the students.

Students' motivation is an aspect that can be associated with the medium-term attractiveness of the courses and the impact that the students perceive they will have in their professional development. Hence, the results of the qualitative stage indicate that commitment is an important component. This conclusion is relevant for the Energy lab MOOCs, given that they are aimed to train professionals who will deploy what they have learned in organizations that are going to demand specialized knowledge and technical skills. Despite the generalized uncertainty of the economic and geopolitical contexts in emerging countries [51], these MOOCs offer opportunities with high potential for professionals to apply what they have learned in practical and interesting projects that will impact their communities in favorable ways [16], [50].

Moreover, the results indicate that time is deemed to be a key factor of the success of the MOOCs. Therefore, students' engagement could be improved with an instructional design that ensures availability of students through asynchronous learning activities or enforcing the development of soft competencies related to time management. With this latter in place, the study load would cease to be a major objection to successfully finish the courses.

These results have been built upon a robust set of data and instruments supported by an efficient combination of qualitative and quantitative techniques. Therefore, in spite of the single source represented by the Energialab MOOCs, the samples offer significant results that might be used for further research that complement the current findings. This study can also be useful to build research projects that develop the same methods over similar populations of students so as to further analyze the frequently low completion ratio and its determinants [52].

In the final stage of the analysis of results, the researchers reviewed and contrasted the information obtained, both from the quantitative section and from the qualitative section, since both views of information must come together to explain the social reality under study [44].

\section{Conclusions}

In this study, the results of the quantitative and qualitative analyzes were presented, and both the hypotheses and the assumptions of the investigation were verified. The data confirm the favorable response of the students regarding the results obtained when finishing the MOOC, both in the factors of professional development and in relation to the specific competencies acquired. Likewise, it is appreciated that there are no significant elements that indicate a difference between the perceptions of these two aspects.

The 2799 participants who completed the open, innovative MOOC on issues of energy sustainability perceived favorably their achievement of their learning objectives in relation to their initial expectations, as verified statistically. There are no indications that this perception is different between the specific competencies acquired and the aspects of professional development.

The participants of the MOOC perceived that they developed professionally in training and learning about energy issues and that they now have business opportunities and new professional relationships open to them. In addition to the successful completion of the MOOC, they have strengthened their perseverance and self-study skills, as well as the use of ICT.

The specific competencies and the degree in which they comprise the perception of the students about their achievements or success in the MOOC are yet to be investigated in future research projects. Similarly, it would be revealing to assess whether there are specific patterns or combinations of competencies that are more valued by the students and, if so, how these perceptions are aligned with a specific set of technical knowledge received during the MOOCs.

One example of these research possibilities would be the analysis of the influence of highly-developed collaborative skills on the success in technical, mathematics or statistics courses compared to courses that offer risk management or financial administration contents.

From the qualitative analysis, it is important to highlight that the students' commitment to the course is mainly determined by the possibility of obtaining a certificate. In addition, in cases in which a student expresses his open opinion, his commitment is stronger when there is an ulterior purpose, that is, a plan to take advantage of the knowledge acquired in favor of his personal or professional development. This result agrees with that of the quantitative analysis, as long as there are no differences in the students' perception of their achievements comparing the professional development aspects with the specific competencies acquired.

Finally, it is identified that time management is considered one of the principle objections perceived by the student when considering the MOOCs. In this case, it would be useful to test the impact of innovative learning techniques upon this component of the students' commitment. Indeed, gamification may increase the engagement of the students, while complementary time management courses may give them tools to face overloaded study schedules. And perhaps, the instructional design can be modified to adapt it to the students' more specific needs, contexts and priorities.

Acknowledgements This paper is presented in the framework of the Project 266632 of the "Binational Laboratory for the Management of 
Intelligent Energy Sustainability and Technology Education" (with funding from the Energy Sustainability Fund CONACYT-SENER, Call: S0019-2014-01). The support of CONACYT and Tecnologico de Monterrey is appreciated. The authors also would like to acknowledge the financial and the technical support of Writing Lab, TecLabs, Tecnologico de Monterrey in the production of this work.

Open Access This article is distributed under the terms of the Creative Commons Attribution 4.0 International License (http://creativeco mmons.org/licenses/by/4.0/), which permits unrestricted use, distribution, and reproduction in any medium, provided you give appropriate credit to the original author(s) and the source, provide a link to the Creative Commons license, and indicate if changes were made.

\section{References}

1. García-Peñalvo, F.J., García de Figuerola, M., Merlo, J.A.: Open knowledge: challenges and facts. Online Inf. Rev. 34(4), 520-539 (2010)

2. Ramírez-Montoya, M.S.: Acceso abierto y su repercusión en la Sociedad del Conocimiento: Reflexiones de casos prácticos en Latinoamérica. Educ. Knowl. Soc. 16(1), 103-118 (2015). https ://doi.org/10.14201/eks2015161103118

3. Bi, Y., Yang, L.: University Interdisciplinary Research Organizations in the Process of Collaborative Innovation: Advantages, Difficulties and Strategies. International Journal of Higher Education 4(1), 71-76 (2015). https://doi.org/10.5430/ijhe.v4n1p71

4. Jiménez Herrero, L.M.: Desarrollo Sostenible: Transición Hacia la Coevolución Global. Madrid, Pirámide (2000)

5. Amemiya, M.: Energía y Sustentabilidad: Algunas Características de la Energía Sustentable. Rev. Dig. Univ. 2010, 13, 1607-6079. http://www.revista.unam.mx/vol.13/num10/art102/ (2010). Accessed 30 Oct 2017

6. Willrich, M.: Energy and World Politics. The Free Press, New York (1975)

7. Li, S., Li, R.: Energy sustainability evaluation model based on the matter-element extension method: a case study of Shandong Province, China. Sustainability 9, 2128 (2017). https://doi. org/10.3390/su9112128

8. Cîrstea, S., Moldovan-Teselios, C., Cîrstea, A., Turcu, A., Darab, C.: Evaluating renewable energy sustainability by composite index. Sustainability 10, 811 (2018). https://doi.org/10.3390/ su10030811

9. Lozano, F., Gándara, G., Perni, O., Manzano, M., Hernández, D., Huisingh, D.: Un Curso de desarrollo sostenible para educar a los educadores. In: Proceedings of the Congreso de Investigación, Innovación y Gestión Educativas, Monterrey, Mexico, 2007; Narváez Castellanos, C., de Sánchez, N.Y. (eds.) ITESM: Monterrey, Mexico, 2008, pp. 244-251. https://repositorio.itesm .mx/bitstream/handle/11285/573793/DocsTec_7277.pdf (2007). Accessed 12 Feb 2018

10. Bartolomé, A.: Blended learning. Conceptos básicos. Píxel-Bit Rev. Medios Educ. 23, 7-20 (2004). https://dialnet.unirioja.es/ servlet/articulo?codigo=892487. Accessed 17 Feb 2016

11. Mercado-Varela, M.A., Fernández-Morales, K., Lavigne, G., Ramírez-Montoya, M.S.: Enseñanza y difusión sobre el uso de recursos educativos abiertos con MOOC: un estudio de caso. Revista de Investigación Educativa 26(1), (2018). https://repos itorio.itesm.mx/bitstream/handle/11285/628007/MrtinMerca do\%20CPU.pdf?sequence=1\&isAllowed=y. Accessed $10 \mathrm{Apr}$ 2018
12. Baturay, M.H.: An overview of the world of MOOCs. Procedia Soc. Behav. Sci. 174, 427-433 (2015). https://ac.els-cdn.com/ S1877042815007363/1-s2.0-S1877042815007363-main.pdf? $\mathrm{tid}=$ dab52a79-98c3-48b3-8c36-8f67fb9f0bbb\&acdnat $=15243$ 12361_570e4b206515c828348f8452311d8ec9. Accessed 7 Feb 2018

13. Benet-Gil, A.: Nuevos horizontes formativos: una experiencia del MOOC como recurso en la formación continua. Apertura 10(1) (2018). http://www.udgvirtual.udg.mx/apertura/index.php/apert ura/article/view/1151/890. Accessed 3 Nov 2018

14. Quiliano, R., Ramírez-Hernández, D. \& Barniol, P. Systematic Mapping Study 2012-2017: Quality and effectiveness measurement in MOOC. Turk. Online J. Distance Educ. 20(1), 223-247 (2018). https://doi.org/10.17718/tojde.522719

15. Grigoroudis, E., Kouikoglou, V.S., Phillis, Y.A.: Energy sustainability of countries. In: Handbook of Research on Sustainable Development and Economics, pp. 96-117. IGI Global (2015)

16. Sikdar, S.K., Sengupta, D., Mukherjee, R.: Energy sustainability, water sustainability. In: Measuring Progress Towards Sustainability, pp. 221-273. Springer, Cham. https://doi.org/10.1007/978-3319-42719-5_9 (2017)

17. McAuley, A., Stewart, B., Siemens, G., Cormier, D.: The MOOC model for digital practice: massive open online courses: digital ways of knowing and learning. http://www.elearnspace.org/Artic les/MOOC_Final.pdf (2010). Accessed 5 Nov 2018

18. Scopeo: Scopeo informe $\mathrm{N}^{\circ} 2$ : MOOC: Estado de la situación actual, posibilidades, retos y futuro\|. Junio, 2013. Scopeo Informe No. 2. http://scopeo.usal.es/wp-content/uploads/2013/06/scope oi002.pdf (2013). Accessed 5 Nov 2018

19. Ruiz-Morales, Y., García-García, M., Biencinto-López, C., Carpintero, E.: Evaluación de competencias genéricas en el ámbito universitario a través de entornos virtuales: Una revisión narrativa. RELIEVE 23(art. 2), 2 (2017). https://doi.org/10.7203/ relieve.23.1.7183

20. Marzal, M.A., Borges, J.: Modelos evaluativos de Metaliteracy y alfabetización en información como factores de excelencia académica. Revista Española de Documentación Científica 40(3), 184 (2017)

21. Ramírez-Montoya, M.S., González del Bosque, S.A., Farías Gaytán, S.C., Ricaurte Quijano, P., Ramírez-Hernández, D.D.C.: Experiencias en el desarrollo e implementación de MOOC de energía y presentación del libro de energía. https://repositori o.itesm.mx/bitstream/handle/11285/627998/171212-MOOCd eEnergia.pdf?sequence $=1$ (2017). Accessed 3 Nov 2018

22. Hernández-Carranza, E.E., Romero-Corella, S.I., Ramírez-Montoya, : Evaluación de competencias digitales didácticas en cursos masivos abiertos: Contribución al movimiento latinoamericano. Comunicar (2017). https://doi.org/10.3916/c44-2015-09

23. Merino, J.M., Mathiesen, M.E., Domínguez, P., Rodríguez, C., Soto, M.E.: Impacto de un programa de desarrollo profesional docente en la calidad del ambiente para la alfabetización emergente. Perfiles Educativos 40(159), 35-50 (2018). http://www. iisue.unam.mx/perfiles/articulos/2018/n159a2018/mx.pered u.2018.n159.pdf\#page=37. Accessed 21 Apr 2018

24. Kasine, Y., Babenko-Mould, Y.B., Regan, S.: Translating clinical education to nursing practice in Rwanda: enhancing maternal and newborn health. Int. J. Afr. Nurs. Sci. 8, 75-81 (2018). https://doi. org/10.1016/j.ijans.2018.03.001

25. Jacinto, C.: Nuevas lógicas en la formación profesional en Argentina Redefiniendo lo educativo, lo laboral y lo social. Perfiles educativos 37(148), 120-137 (2015). https://doi.org/10.1016/j. pe.2015.11.011

26. Le Boterf, G.: L'ingénierie des competénces. Ingeniería de las competencias. Barcelona. Gestión 2000. (2001)

27. Edel-Navarro, R., Ruiz-Méndez, G., Sánchez-Matías, N.: La plataforma MéxicoX en el aprendizaje abierto y en línea: aproximación 
a los massive open online courses. Eduscientia 1(1), 4-29 (2018). http://www.eduscientia.com/index.php/JOURNAL/article/downl oad/29/21. Accessed 24 Oct 2018

28. Creswell, J.W., Plano Clark, V.L.: Designing and Conducting Mixed Methods Research. Sage, Thousand Oaks (2007). https:// doi.org/10.1177/1558689807306132

29. Hernández-Sampieri, R., Fernández-Collado, C., Baptista-Lucio, P., Pérez, M.D.L.L.C.: Metodología de la investigación, vol. 1. Mcgraw-Hill, México (2006)

30. Coe, R., Waring, L., Hedges, L.V., Arthur, J.: Research Methods \& Methodologies in Education, 2nd edn. SAGE Publications, London (2017)

31. Cohen, L., Manion, L., Morrison, K.: Research Methods in Education. Routledge, London (2013)

32. Valenzuela, J., Flores, M.: Fundamentos de investigación educativa. Tecnológico de Monterrey, México (2014). (E-book)

33. Valdivia, J.A., Valenzuela, J.R., Ramírez-Montoya, M.S.: Pilotaje de validez de contenido de instrumentos MOOC. Documento inédito. https://repositorio.itesm.mx/bitstream/handle/11285 /622345/170210-Reporte\%20Pilotaje\%20Instrumentos.pdf?seque nce $=1 \&$ isAllowed $=y$ (2017). Accessed 24 Oct 2018

34. Valdivia, J.A.: Encuesta inicial sobre intereses, motivaciones y conocimientos previos en MOOC: Reporte de validación y confiabilidad. Documento no publicado, Escuela de Humanidades y Educación, Tecnológico de Monterrey, Monterrey, México. https ://repositorio.itesm.mx/ortec/bitstream/11285/622442/1/Encue sta_inicial_motivacioonesMOOC.pdf (2017). Accessed 7 Feb 2018

35. Valdivia-Vázquez, J.A., Ramírez-Montoya, M.S., ValenzuelaGonzález, J.R.: Motivation and Knowledge: Pre and Post Assessment of MOOC participants from an Energy and Sustainability Project. https://repositorio.itesm.mx/bitstream/handle/11285 /628036/180214_Valdivia_AssessClean.pdf?sequence $=3$ \&isAll owed $=\mathrm{y}$ (2018). Accessed 3 Nov 2018

36. Oviedo, H.C., Arias, A.C.: Aproximación al uso del coeficiente alfa de Cronbach. Revista colombiana de psiquiatría 34(4), 572-580 (2005). http://www.redalyc.org/pdf/806/80634409.pdf. Accessed 23 Nov 2017

37. Tashakkori, A., Teddlie, C.: SAGE Handbook of Mixed Methods in Social and Behavioral Research. SAGE Publications, London (2005). (Kindle Edition)

38. Ugalde, N., Balbastre-Benavent, F.: Investigación cuantitativa e investigación cualitativa: buscando las ventajas de las diferentes metodologías de investigación. Revista de Ciencias económicas, 31(2), 179-187 (2013). https://revistas.ucr.ac.cr/index.php/econo micas/article/viewFile/12730/11978. Accessed 2 Oct 2017

39. Vega-Malagón, G., Ávila-Morales, J., Vega-Malagón, A., Camacho-Calderón, N., Becerril-Santos, A., Leo-Amador, G.: Paradigmas en la Investigación. Enfoque cuantitativo y cualitativo. Eur. Sci. J. ESJ 10(15) (2014). http://www.eujournal.org/index.php/ esj/article/viewFile/3477/3240. Accessed 2 Oct 2017

40. Ramírez-Montoya, M.S.: Desarrollo de innovación abierta, interdisciplinaria y colaborativa [informe técnico]. Tecnológico de Monterrey. Monterrey, México. https://repositorio.itesm.mx/ bitstream/handle/11285/628048/2018-2-Desarrollo\%20innovaci on.pdf?sequence $=1 \&$ is Allowed=y (2018). Acessed 4 Oct 2018
41. Arriaza, B.M.: Guía práctica para el análisis de datos. Andalucía, España. Junta de Andalucía. Consejería de Innovación, Ciencia y Empresa. Instituto de Investigación y Formación Agraria y Pesquera. http://www.juntadeandalucia.es/agricultur aypesca/ifapa/-/action/90004fc0-93fe-11df-8d8b-f26108bf46 ad/e5747030-1bb8-11df-b7e2-35c8dbbe5a83/es/02f9e190-faff11e0-929f-f77205134944/alfrescoDocument?i3pn=contenidoA lf $\& \mathrm{i} 3 \mathrm{pt}=\mathrm{S} \& \mathrm{i} 31=\mathrm{es} \& \mathrm{i} 3 \mathrm{~d}=\mathrm{e} 5747030-1 \mathrm{bb} 8-11 \mathrm{df}-\mathrm{b} 7 \mathrm{e} 2-35 \mathrm{c} 8 \mathrm{dbbe} 5 \mathrm{a}$ 83\&contentId=1c141ba8-08cc-42fc-9df7-10a632eb3194 (2006). Accessed 4 Jan 2017

42. Fundación Telefónica: Los MOOC en la Educación del Futuro: La Digitalización del Futuro, pp. 50-77. Editorial Ariel, Barcelona, Spain. ISBN: 978-84-08-13942-3 (2015)

43. Robles, V.P., Ruíz, J.E.Z.: Implementación de un MOOC en cursos presenciales como estrategia para elevar el rendimiento académico. Innoeduca Int. J. Technol. Educ. Innov. 2, 38-45 (2016). https://doi.org/10.20548/innoeduca.2016.v2i1.1065

44. Monje-Alvarez, C.A.: Metodología de la investigación cuantitativa y cualitativa. Guía didáctica. Universidad Surcolombiana, Neiva, Colombia (2011)

45. Hernández, R., Fernández, C., Baptista, P.: Metodología de la Investigación, 5th ed. McGraw-Hill, Mexico. ISBN 978-607-150291-9 (2010)

46. The United Nations Educational, Scientific and Cultural Organization (UNESCO): Guía Básica de Recursos Educativos Abierto (REA). UNESO, París, France, ISBN 978-9-233000-20-9. (2015)

47. Vadillo, G.: Masivos e íntimos: La presencia social en los MOOC. Rev. Dig. Univ. 17, 1 (2016). http://www.revista.unam.mx/vol.17/ num1/art02/index.html. Accessed 14 July 2017

48. Méndez, C.: Diseño e implementación de cursos abiertos masivos en línea (MOOC): Expectativas y consideraciones prácticas. RED. Rev. Educ. Distancia 39, 58-77 (2013). http://www.redalyc.org/ articulo.oa?id=54729539004. Accessed 13 Apr 2017

49. Alemán de la Garza, L., Sancho-Vinuesa, T., Gómez Zermeño, M.: Indicadores de calidad pedagógica para el diseño de un curso en línea masivo y abierto de actualización docente. RUSC. Univ. Knowl. Soc. J. 12(1), 104-119 (2015). https://doi.org/10.7238/ rusc.v12i12260

50. Argüeta-Velázquez, M.G., Ramírez-Montoya, M.S.: Innovación en el diseño instruccional de cursos masivos abiertos con gamificación y REA para formar en sustentabilidad energética. https ://gredos.usal.es/jspui/bitstream/10366/136069/1/Innovacion _en_el_diseno_instruccional_de.pdf (2017). Accessed 7 Feb 2018

51. Romo, D.: Refinación de petróleo en México y perspectiva de la Reforma Energética. Problemas del desarrollo 47(187), 139-164 (2016). https://doi.org/10.1016/j.rpd.2016.10.005

52. Chiappe-Laverde, A., Hine, N., Martínez-Silva, J.: Literatura y práctica: Una revisión crítica acerca de los MOOC. Comunicar 22, 9-18 (2015). https://doi.org/10.3916/C44-2015-01

Publisher's Note Springer Nature remains neutral with regard to jurisdictional claims in published maps and institutional affiliations. 